\title{
Impact of refugee population on development: A comparative analysis for the case of host economies
}

\author{
Mohamed Kouni ${ }^{1}$
}

\begin{abstract}
This study was carried out to investigate the relationship between refugees and development in host economies from a macroeconomic point of view. The results obtained show that this relationship is non-linear. The empirical results demonstrate that refugees have a positive and significant direct effect in high and lower-middle-income countries. A positive and significant indirect effect of refugees through labor force and $\mathrm{RD}$ channels is also present in the same groups. In upper-middle-income and lowincome countries, the direct effect of refugees is negative and significant. Similarly, the indirect effect of the refugee population on development through labor force channel is also negative and statistically significant. However, the indirect effect of refugees through RD channel is statistically significant only for the low-income country group.
\end{abstract}

Keywords:, Economic development, GMM-method, growth, refugees.

JEL code: O1,C32, O4,F22

Received: 27 November 2017 / Accepted: 17 January 2018/Sent for Publication: 8 March 2018

\section{Introduction}

Refugee crises around the world nowadays rank among the greatest priorities for both developed and developing countries internationally. Recently, thousands of refugees have crossed the borders of a neighboring (or non-neighboring) country due to violence, war or other various political issues. Indeed, the most recent refugee crises in Syria, Iraq, Myanmar, Egypt, Yemen or Libya have reinforced the international refugee situation in an extent that has not been registered since the Second World War. In fact, the number of refugees has increased rapidly over the last 35 years. United Nations High Commissioner for Refugees (UNHCR) estimates the number of refugees to be more than 65 million people who moved from their home countries abroad. This number was 5.7 million in 1980, 9 million in 2005 and 42.3 million in 2009 (AlixGarcia and Saah, 2008 and Gomes et al., 2010). In addition, 55\% of the world's

\footnotetext{
${ }^{1}$ Assistant professor of economics at the Higher Institute of Business Administration, University of Gafsa, Rue Houcine Ben Gaddour, Sidi Ahmed Zarroug, Gafsa, 2112, Tunisia. kouni.mo@gmail.com
} 
refugees only come from three countries: Syria (5.5 million), Afghanistan (2.5 million) and South Sudan (1.4 million). Gomes et al. (2010) state that, the majority of refugees in the world head to low or middle-income countries. Similarly, UNHCR have assessed that the top hosting countries are Turkey (2.5 million), Pakistan (1.4 million), Lebanon (1 million), Iran $(979,400)$, Uganda $(940,800)$, and Ethiopia $(791,600)$. Previous studies such as the work of $\mathrm{Li}(2008)$ have shown that only a small number of refugees are located in developed countries.

In terms of scientific research, only a few studies have focused on the refugee field compared to the number of those conducted on the migration field. The majority of studies, if not all, were carried out on micro-data and were only limited to a sample of refugees. These studies have proven that the impact on host economies is not exclusively negative.

On the contrary: several works have proven that there can be both a negative and a positive effect of refugee migration on economic variables in host countries. Kreibaum (2016) reports that refugee camp generates a positive externality in terms of consumption and public services on Ugandan population living in close proximity to refugees. Kibreab (1985) has long ago proven that refugees can positively stimulate development and help increase financial and human resources in the host society. Moreover, Gomes et al. (2010) also demonstrate how the effect of the refugee population on the host country is not always negative but can have rather significant positive effects on the host society.

This paper contributes to the growing number of quantitative and qualitative literature conducted on the effects of refugee population on host economies in some aspects. To the best of our knowledge, this study is one of the few essays in which the effect of refugees is investigated from a macroeconomic point of view. Most of the previous studies analyze this effect using a relatively small number of refugees (from surveys) and small host communities, from which authors aggregate the results. The aggregation of results based on micro-data is very limited and overall insufficient. (Baez, 2011). In this paper, a macro-data set of 21 countries is used to test the effects of refugees on development. We have estimated a dynamic panel model through which the direct and indirect effects of refugees on GDP per capita of 4 income-groups are measured. It is also important to note that the indirect effect has been poorly analyzed in the literature so far, despite its importance. Similarly, previous studies do not make any comparison, in terms of the effects of refugees, between countries or groups of host countries.

Obtained results reveal that the relationship between refugee population and development is non-linear. Moreover, the empirical results demonstrate that refugees have a positive and significant direct effect on high-income and lower-middle-income countries. A positive and significant indirect effect of refugees through labor force and $\mathrm{RD}$ channels is also present for the same groups. As for the rest of the groups, the direct effect of refugees is negative and significant. The indirect effect of refugee population on development through labor force channel is also negative and statistically significant. However, their indirect effect through RD channel is only statistically significant for the low-income countrygroup. 
The paper is structured as follows: the chapter following the introduction presents a brief literature review. The third chapter examines the empirical impact of refugees on development; and, finally, the fourth chapter is devoted to a summary and conclusion.

\section{The effect of refugee population on host economies: Literature review}

Many studies have been conducted on the migration field. However, only a few of them take the effect of refugees on host economies into consideration. The movement of refugees is, in fact, different from migration because it is forced and involuntary. Considering this, the effect of refugees as a part of the entire diaspora is different from that of the rest of immigrants. Host countries do not treat the refugee population as voluntary immigrants, thus specific measures are taken. For example, aid is granted to refugees such as humanitarian subsidies. Nonetheless, some restrictions can also be adopted such as the prohibition of work or movement. Due to the specific nature of the refugee problematic, the study of the effect of refugees on host economies becomes very important in order to remove the ambiguity concerning the real effect of refugees. The studies that have addressed this issue, despite their scarcity, prove that there can be both a negative and a positive effect of refugees on host economies. Kreibaum (2016) is the first author to conduct an empirical study on the long-term effect of refugee population on local communities in Uganda. The author reports that a refugee camp generates a positive externality on Ugandan population living in close proximity to the refugees. This population then benefits in terms of consumption and public services. Kibreab (1985) has proven that refugees can stimulate growth and development in the asylum country if they are given rights such as an access to labor and goods markets. Refugees also enable an increase in financial and human resources in the host society. Therefore, the demand in the host economy (especially for the middle or low-income countries) will increase and financial resources coming from donors will also rise to improve the living standards of the population (Baez, 2011 and Jacobsen, 2002).

Alix-Garcia and Saah (2008) state that prices of agricultural goods have increased with Rwandan inflows, thereby, increasing the share of non-agricultural goods of Tanzanian population. Similarly, Maystadt and Verwimp (2009) find a positive effect of refugee inflows originating from Burundi and Rwanda on consumption. This effect depends on the activities of Tanzanian citizens who can be advantageous if they work in nonagricultural sphere, or are self-employed farmers.

Shellito (2016) identifies the positive and negative impact of refugees on the host economies that can be concluded based on already conducted academic studies. The author reports that the positive effects can be summarized as follows:

- Refugees can stimulate long-term investment,

- They boost consumption and production and, therefore, productivity,

- $\quad$ They can fill demographic gaps and increase labor supply, or

- They stimulate an increase in trade between host and origin countries.

On the other hand, the host society can notice some negative effects, such as: 
- Increase of public and private charges,

- Overcrowding, or

- Increase in conflicts within the community.

Gomes et al. (2010) demonstrate that the effect of the refugee population on the host country is not always negative but can have a rather significant positive effect on the host society. The authors of the study also note that the total of annual benefits collected by the host community as a result of the camp operation in Kenya was about 82 million dollars in 2009 and 100 million dollars in 2010. Furthermore, the refugees received remittances sent from other countries (mostly from developed ones) by their relatives. As a result, these funds contributed to the growth of the host economy.

There are indeed both positive and negative effects of refugee population on host economy. Nevertheless, the net effect is an issue that remains to be discussed. It depends on the integration degree of refugees in the host society. Jacobsen (2001) has conducted a study on local integration of refugees in developing countries by describing the difficulties the refugees face in the integration into the host society where a resistance to integration can occur due to security issues or limited economic resources.

Whereas some studies have assessed that only a small part of the world's refugee population is settled in developed countries (Gomes et al., 2010 and Li, 2008). This means that there is a selective policy adopted by OECD countries. Li (2008) reports that advanced countries such as Australia, Canada or the United States of America have benefited from immigration because they attract high-skilled workers from developing countries. In 2006, The United Nations estimated the number of refugees to be about 13.5 million, where $80 \%$ settled in less-developed countries and only $20 \%$ in developed countries that took in more than $60 \%$ of immigrants, especially skilled workers. This signals that the refugee migration to developed countries was relatively restrictive compared to the voluntary migration. Li (2008) confirms that the OECD countries adopt a very restrictive asylum policy, despite the small flow of asylum seekers. In addition, there is a significant competition between industrialized countries adopting the same restrictive strategy towards immigration in attracting highly skilled refugee workers.

\section{Empirical evidence}

The objective of this section is to investigate the effect of refugee population on GDP per capita growth rate. To carry out this analysis, a macroeconomic framework similar to the one used in the growth literature is applied. It is important to emphasize that the majority of studies conducted in this field, if not all, adopt a microeconometric approach, as can be seen in Kreibaum (2016), Baez (2011) or Maystadt and Verwimp (2009). For the purpose of this paper, we have built a panel of 21 developed and developing countries in order to estimate a model which fits into a theoretical framework of works treating the impacts of immigration on host economies as in Borjas (1994) or Freidberg and Hunt (1995). Indeed, the following equation is estimated: 
$\ln (\text { per capita_GDP })_{\mathrm{i}, \mathrm{t}}=\mathrm{c}_{0}+\mathrm{c}_{1} \ln (\text { per capita_GDP })_{\mathrm{i}, \mathrm{t}-1}+\mathrm{c}_{2} \ln \left(\frac{\text { gfcf }}{\mathrm{GDP}}\right)_{\mathrm{i}, \mathrm{t}}+$

$c_{3} \ln \left(\frac{\text { Refugee }}{\mathrm{x}}\right)_{\mathrm{i}, \mathrm{t}}+\mathrm{c}_{4}\left(\ln \left(\frac{\text { Refugee }}{\mathrm{x}}\right)_{\mathrm{i}, \mathrm{t}}\right)^{2}+\mathrm{c}_{5} \ln (\text { Refugee })_{\mathrm{i}, \mathrm{t}} * \ln \left(\right.$ lf $\mathrm{i}_{\mathrm{i}, \mathrm{t}}+\mathrm{c}_{6} \ln (\text { Refugee })_{\mathrm{i}, \mathrm{t}}$ *

$\ln (\mathrm{tsja})_{\mathrm{i}, \mathrm{t}}+\mathrm{c}_{7} \ln (\mathrm{tsja})_{\mathrm{i}, \mathrm{t}}+\mathrm{c}_{8} \ln (\mathrm{com})_{\mathrm{i}, \mathrm{t}}+\varepsilon_{\mathrm{i}, \mathrm{t}}$

With percapita_GDP, $\frac{g f c f}{G D P}, \frac{R e f u g e e}{X}, l f, t s j a$ and com being the annual real GDP per capita, the gross fixed capital formation divided by GDP, refugee rate, labor force, the number of scientific and technical journal articles and openness rate, respectively.

\subsection{Data}

Variables: data sources and definitions

The data used for this study have been collected from the World Bank (World Development Indicators) and cover the period from 1990 to 2014. The variables used in Equation 1 can be defined as follows:

Dependent variable: The dependent variable is the annual real GDP per capita $\left(\ln \left(\right.\right.$ percapita_GDP $\left._{i, t}\right)$. Economic literature considers GDP per capita as a macroeconomic indicator of development. Its increase also reflects the well-being of the population.

\section{Independent variables:}

- The annual real GDP per capita of the last period ( $\ln \left(\right.$ percapita_GDP $\left._{i, t-1}\right)$ : the lagged value of the dependent variable used here in order to better show the dynamics of growth. The development process is indeed cumulative and the historical development level is one of the main factors of its current state. The expected sign of its coefficient $\left(c_{1}\right)$ is hence positive.

- The gross fixed capital formation is divided by GDP $\left(\ln \left(\frac{g f c f}{G D P}\right)_{i, t}\right)$ : this variable is a proxy variable of capital. Investment (gfcf) constitutes a major factor of growth and therefore of development. Consequently, the expected sign of its coefficient $\left(c_{2}\right)$ is positive.

- The refugee rate $\left(\ln \left(\frac{\text { Refugee }}{X}\right)_{i, t}\right)$ : It has been measured in two different ways: firstly as a ratio between the number of refugees and host population $(X=$ host population), and then as a ratio between the number of refugees and the total labor force in the host society (X=labor force). It is important to note that if refugees are wellintegrated into society and become a part of labor force, they contribute to growth in the countries where the labor supply is insufficient. In such a case the second measure would be more appropriate than the first. The sign of its coefficient $\left(\mathrm{c}_{3}\right)$ can be positive or negative.

- The squared refugee rate $\left(\left(\ln \left(\frac{\text { Refugee }}{x}\right)_{i, t}\right)^{2}\right)$ : This variable is used to test the quadratic relationship between the refugee population and development. If this relationship is proven, the sign of the coefficient of the squared refugee rate $\left(c_{4}\right)$ 
opposes the one of refugee rate $\left(c_{3}\right)$. It also shows the impact of refugees on development once their number significantly grows.

- Interactive variables ( $\left.\ln (\text { Refugee })_{i, t} * \ln (l f)_{i, t}\right)$ and $\left(\ln (\text { Refugee })_{i, t} *\right.$ $\left.\ln (\operatorname{tsja})_{i, t}\right)$ : in order to determine the indirect effect of refugees on development, two interactive variables have been established. It is possible for refugees to generate a nonlinear impact on host economy. They affect development through channels like labor force and/or research and development activity. It is evident that there are two refugee categories recognized by host countries: skilled and unskilled workers who contribute to growth and the increase in labor supply and/or productivity especially in economies where the labor supply is insufficient. Skilled refugees may also boost research in the host country, particularly when it adopts a very selective asylum policy. For this purpose, the two channels through which refugees can contribute to the growth and development are labor force ( $l f$ ) and research and development. The latter has been approximated by the number of scientific and technical journal articles (tsja). The expected sign of the coefficient $\left(c_{5}\right.$ and $c_{6}$ ) indicating an indirect effect of refugees through the two above-mentioned channels is positive or negative.

- The number of scientific and technical journal articles $\left(\ln (\operatorname{tsja})_{i, t}\right)$ : this variable serves as a proxy of the research and development indicator (RD). The statistics for research and development expenditure are not available for all countries and for the full of the period from 1990 to 2014. Nonetheless, the number of journal articles reflects the research activity well and allows for a real technological comparison between the countries. The expected sign of its coefficient $\left(c_{7}\right)$ is positive as RD constitutes one of the main growth factors. Romer (1990) and Grossman and Helpman (1991) consider $\mathrm{RD}$ to be a major factor of growth, especially in developed countries.

- $\quad$ The openness rate $\left(\ln (\mathrm{com})_{i, t}\right)$ : openness rate has been calculated as the ratio between the sum of import and export and GDP. It is also considered to be among the main variables of growth. Therefore, its coefficient $\left(c_{8}\right)$ is expected to be positive.

All variables are in a logarithmic form. Additionally, to deal with the problem of multicollinearity (see Appendix A3) we have estimated Equation 1 which is consistent with the econometric literature, considering the correlated independent variables. For this purpose, in each regression effectuated we only took into consideration one refugee variable.

\section{Sample}

Our sample includes 21 developed and developing countries. We have estimated the model for each income-group in compliance with the 2014 World Bank classification. The World Bank classifies countries into four groups according to their income: highincome group, upper-middle-income group, lower-middle-income group and lowincome group. The countries in the sample compose of 9 high-income countries, 4 upper-middle-income countries, 4 lower-middle-income countries and 4 low-income countries. In order to solve the problem of heterogeneity we have estimated the model for each income group. 


\subsection{Methodology}

The methodological approach of the paper lies in the estimation of Equation 1 by the Generalized Method of Moments (GMM). If the dynamic panel-data model contains $n$ lags of the dependent variable as well as unobserved fixed or random effects, the standard estimator becomes inconsistent as these effects are correlated with the lagged dependent variable. Therefore, it appears that the best estimates could be obtained when the GMM method is applied. We used the Arellano and Bond (1991) estimator and the dynamic panel-data estimator of the system (Arellano- Bover, 1995 and Blundell- Bond, 1998). The GMM enables us to control individual and temporal specific effects and to palliate the endogeneity bias of variables. In the Arellano and Bond (1991) estimator, the strategy is to differentiate Equation 1 in level. The first difference eliminates the country's specific effect and, therefore, the bias of omitted variables. Consequently, the first differences of exogenous variables are instrumented by their lagged values. The simultaneity bias and the bias introduced by the presence of the lagged endogenous variable are reduced. Furthermore, the system dynamic panel-data estimator method combines the equation in difference with the one in level. Both equations have been estimated simultaneously using the GMM method. For two of the estimators it is assumed that the variables are stationary in level and the residues are not autocorrelated.

For each country-group in this study, we adopted the method that gives the most significant estimates out of the two estimators.

\subsection{Empirical results}

Results are shown in following four tables (from Table 1 to Table 4). It clearly appears that the model is statistically significant in all regressions. Furthermore, estimated coefficients attached to most variables are statistically significant at the 1\% and 5\% levels. For example, the refugee population generates a statistically significant effect in all country groups. In fact, despite the fact that this effect differs with every group, it is significant at $1 \%$ to $5 \%$ level in all estimates. Therefore, it is positive and significant at $1 \%$ and $5 \%$ for high-income group (Table 1) and lower-middle-income group (Table 3), respectively.

However, the impact of refugee rate on GDP per capita is negative and significant at $1 \%$ level for the upper-middle-income group (Table 2) and the low-income group (Table 4). It is also important to note that the two refugee rate measures create a similar effect (the elasticity of per capita GDP with respect to refugee variables varies from about 0.0054 for high-income countries to about 0.0045 for lower-middle-income countries). Whether this rate is calculated as the ratio of the number of refugees to the population or the ratio of the number of refugees to the labor force, the result is almost the same in all regressions. Refugee population obviously exerts a positive effect on the development of high-income and lower-middle-income countries, in accord with an important body of the recent literature. For these countries, refugees contribute to growth positively and significantly, but they do not have the same impactdegree in all countries. Hence, this impact is more important and significant for high-income countries than for the lowermiddle-income countries. The elasticity of GDP per capita with respect to refugee rate is 
the highest and most significant. It seems that the high-income countries benefit from refugees particularly when their number is reasonably low.

Table 1. GMM results of refugees' impact on development: The case of highincome countries.

\begin{tabular}{|c|c|c|c|c|c|c|}
\hline Variable & $\begin{array}{c}\text { (1) } \\
\text { A-B }\end{array}$ & $\begin{array}{c}(2) \\
\text { A-B }\end{array}$ & $\begin{array}{c}\text { (3) } \\
\text { A-B }\end{array}$ & $\begin{array}{l}\text { (4) } \\
\text { A-B }\end{array}$ & $\begin{array}{l}\text { (5) } \\
\text { A-B }\end{array}$ & $\begin{array}{l}\text { (6) } \\
\text { A-B }\end{array}$ \\
\hline Constant & $\begin{array}{c}2.7156^{* * *} \\
(12.02)\end{array}$ & $\begin{array}{c}2.7168 * * * \\
(12.04)\end{array}$ & $\begin{array}{l}2.7070 * * * \\
(12.03)\end{array}$ & $\begin{array}{c}2.7151^{* * *} \\
(12.10)\end{array}$ & $\begin{array}{c}2.6112^{* * * *} \\
(11.40)\end{array}$ & $\begin{array}{c}2.5739 \text { **** } \\
(11.61)\end{array}$ \\
\hline Ln_GDP per capitat-1 & $\begin{array}{l}.74995^{* * * *} \\
(32.59)\end{array}$ & $\begin{array}{c}.74911 * * * \\
(32.57)\end{array}$ & $\begin{array}{c}.74676 * * * \\
(32.53)\end{array}$ & $\begin{array}{c}.74466 * * * * \\
(32.49)\end{array}$ & $\begin{array}{c}.75121 * * * * \\
(32.60)\end{array}$ & $\begin{array}{c}.77403 * * * \\
(38.52)\end{array}$ \\
\hline ln_gfcf/gdp & $\begin{array}{c}.16481 * * * \\
(13.45)\end{array}$ & $\begin{array}{c}.16551 * * * \\
(13.49)\end{array}$ & $\begin{array}{c}.16716^{* * *} \\
(13.60)\end{array}$ & $\begin{array}{c}.16860 * * * \\
(13.71)\end{array}$ & $\begin{array}{c}.16405^{* * * *} \\
(13.39)\end{array}$ & $\begin{array}{c}.15867 * * * * \\
(13.26)\end{array}$ \\
\hline ln_refugee/pop & $\begin{array}{c}.00535^{* * *} \\
(3.39)\end{array}$ & & & & & \\
\hline$(\text { ln_refugee/pop })^{2}$ & & & $\begin{array}{c}-.0003 * * * \\
(-3.70)\end{array}$ & & & \\
\hline ln_refugee/laborforce & & $\begin{array}{c}.00542 * * * \\
(3.44)\end{array}$ & & & & \\
\hline $\begin{array}{l}\text { (ln_refugee/ } \\
\text { laborforce) })^{2}\end{array}$ & & & & $\begin{array}{c}-.0004 * * * \\
(-3.91)\end{array}$ & & \\
\hline $\begin{array}{l}\text { ln_refugee* }{ }^{*} \text { _llabor } \\
\text { force }\end{array}$ & & & & & $\begin{array}{c}.00033^{* * * *} \\
(3.40)\end{array}$ & \\
\hline ln_refugee* $\ln \_$tsja & & & & & & $\begin{array}{c}.00073 * * * \\
(3.83)\end{array}$ \\
\hline ln_tsja & $\begin{array}{c}.021794 * * * \\
(3.20)\end{array}$ & $\begin{array}{l}.02230 * * * \\
(3.26)\end{array}$ & $\begin{array}{c}.02447 * * * \\
(3.49)\end{array}$ & $\begin{array}{c}.02601 * * * \\
(3.67)\end{array}$ & $\begin{array}{c}.02110^{* * * *} \\
(3.12)\end{array}$ & \\
\hline ln_com & $\begin{array}{c}.041595^{* * * *} \\
(5.03)\end{array}$ & $\begin{array}{c}.04171 * * * \\
(5.05)\end{array}$ & $\begin{array}{c}.03990 * * * \\
(4.81)\end{array}$ & $\begin{array}{c}.03971 * * * \\
(4.80)\end{array}$ & $\begin{array}{c}.04067 * * * \\
(4.89)\end{array}$ & $\begin{array}{c}.05404 * * * \\
(8.12)\end{array}$ \\
\hline Wald chi2(5) & 7770.38 & 7787.72 & 7836.98 & 7885.00 & 7668.14 & 7551.91 \\
\hline Prob > chi 2 & 0.0000 & 0.0000 & 0.0000 & 0.0000 & 0.0000 & 0.0000 \\
\hline $\mathrm{N}$ ofobservations & 205 & 205 & 205 & 205 & 205 & 205 \\
\hline
\end{tabular}

Note: t-statistic in parentheses; ***, **, *: significant at $1 \%, 5 \%$ and $10 \%$ respectively; A-B: Arellano-Bond dynamic panel-data estimation.

Source: Author's calculations 
Table 2. GMM results of refugees' impact on development: The case of uppermiddle-income countries.

\begin{tabular}{|c|c|c|c|c|c|c|}
\hline Variable & $\begin{array}{c}(1) \\
A-B / B-B\end{array}$ & $\begin{array}{c}(2) \\
A-B / B-B\end{array}$ & $\begin{array}{c}(3) \\
A-B / B-B\end{array}$ & $\begin{array}{c}(4) \\
A-B / B-B\end{array}$ & $\begin{array}{c}(5) \\
A-B / B-B\end{array}$ & $\begin{array}{c}(6) \\
A-B / B-B\end{array}$ \\
\hline Constant & $\begin{array}{l}.93144 * * * \\
(3.93)\end{array}$ & $\begin{array}{l}.94552 * * * \\
(4.03)\end{array}$ & $\begin{array}{l}.97846^{* * * *} \\
(4.26)\end{array}$ & $\begin{array}{c}.99223 * * * \\
(4.34)\end{array}$ & $\begin{array}{c}1.11034 * * * \\
(4.99)\end{array}$ & $\begin{array}{c}.67559 * * * \\
(3.32)\end{array}$ \\
\hline Ln_GDP per capita ${ }_{t-1}$ & $\begin{array}{l}.89010 * * * \\
(31.19)\end{array}$ & $\begin{array}{l}.88956 * * * \\
(31.25)\end{array}$ & $\begin{array}{l}.88892 * * * \\
(31.40)\end{array}$ & $\begin{array}{l}.88805^{* * *} * \\
(31.44)\end{array}$ & $\begin{array}{c}.88552 * * * \\
(31.36)\end{array}$ & $\begin{array}{l}.93375 * * * \\
(37.68)\end{array}$ \\
\hline ln_gfcf/gdp & $\begin{array}{l}.02907 * * \\
(2.42)\end{array}$ & $\begin{array}{l}.02878 * * \\
(2.40)\end{array}$ & $\begin{array}{l}.02736^{* * *} \\
(2.24)\end{array}$ & $\begin{array}{l}.02708 * * \\
(2.22)\end{array}$ & $\begin{array}{l}.02576^{* * *} \\
(2.11)\end{array}$ & $\begin{array}{l}.01780 \\
(1.53)\end{array}$ \\
\hline In_refugee/pop & $\begin{array}{c}-.0105 * * * \\
(-2.70)\end{array}$ & & & & & \\
\hline$(\text { ln_refugee/pop })^{2}$ & & & $\begin{array}{l}.00071 * * * \\
(2.94)\end{array}$ & & & \\
\hline ln_refugee/laborforce & & $\begin{array}{c}-.0107 * * * \\
(-2.70)\end{array}$ & & & & \\
\hline $\begin{array}{l}\text { (ln_refugee/ } \\
\text { laborforce) })^{2}\end{array}$ & & & & $\begin{array}{l}.00080^{* * * *} \\
(2.91)\end{array}$ & & \\
\hline $\begin{array}{l}\text { ln_refugee*ln_labor } \\
\text { force }\end{array}$ & & & & & $\begin{array}{c}-.00059 * * \\
(-2.37)\end{array}$ & \\
\hline ln_refugee* ln_tsja & & & & & & $\begin{array}{c}.0000981 \\
(0.24)\end{array}$ \\
\hline ln_tsja & $\begin{array}{l}.01178 * * \\
(2.17)\end{array}$ & $\begin{array}{l}.01152 * * \\
(2.12)\end{array}$ & $\begin{array}{l}.01140^{* * *} \\
(2.10)\end{array}$ & $\begin{array}{c}.01109 * * \\
(2.03)\end{array}$ & $\begin{array}{c}.01529 * * * \\
(2.89)\end{array}$ & \\
\hline ln_com & $\begin{array}{l}.07720 * * * \\
(9.90)\end{array}$ & $\begin{array}{l}.07751 * * * \\
(9.89)\end{array}$ & $\begin{array}{l}.07865^{* * * *} \\
(9.91)\end{array}$ & $\begin{array}{c}.07901 * * * \\
(9.89)\end{array}$ & $\begin{array}{c}.07155^{* * * *} \\
(9.76)\end{array}$ & $\begin{array}{c}.06748^{* * * *} \\
(9.30)\end{array}$ \\
\hline Wald chi2(5) & 7020.59 & 7030.83 & 6985.98 & 6992.03 & 7012.33 & 7149.92 \\
\hline Prob $>$ chi2 & 0.0000 & 0.0000 & 0.0000 & 0.0000 & 0.0000 & 0.0000 \\
\hline $\mathrm{N}$ ofobservations & 96 & 96 & 96 & 96 & 96 & 96 \\
\hline
\end{tabular}

Note: $t$-statistic in parentheses; ***, **, *: significant at 1\%, 5\% and $10 \%$ respectively; $A-B / B-B$ : System dynamic panel-data estimation (Arellano-Bover (1995) and Blundell- Bond (1998)).

Source: Author's calculations

These countries generally require both skilled and unskilled labor. It is also possible, as has been already shown in the previous section that developed countries tend to adopt a very selective asylum policy, and put more restrictions on unskilled households and flexible measures for skilled ones. The need for labor in high-income countries can also be illustrated with the effect of the interactive variable $\left(\ln (\operatorname{Refugee})_{i, t} * \ln (\operatorname{lf})_{i, t}\right)$ measuring the indirect effect of a refugee population through the labor market channel. This effect appears to be positive and statistically significant. The coefficient of the variable is around 0.003 and is significant at $1 \%$ level. The indirect effect of refugees through the research and development sector is positive and also significant at $1 \%$ level. This means that there are some refugees that contribute to the research activity, confirming the selective asylum policy. Moreover, the same result is obtained for lower- 
middle-income countries where the indirect impact of two interactive variables $\left(\ln (\text { Refugee })_{i, t} * \ln (\operatorname{lf})_{i, t}\right)$ and $\left(\ln (\text { Refugee })_{i, t} * \ln (\text { tsja })_{i, t}\right)$ is positive and significant at $5 \%$ level. Despite the fact that these countries are relatively poor and labor-intensive, like Egypt or Bangladesh, refugees engendered a direct and indirect positive and significant effect. This could be explained by a good integration policy in the country.

Table 3. GMM results of refugees' impact on development: The case of lowermiddle-income countries.

\begin{tabular}{|c|c|c|c|c|c|c|}
\hline Variable & $\begin{array}{l}(1) \\
A-B\end{array}$ & $\begin{array}{l}\text { (2) } \\
\text { A-B }\end{array}$ & $\begin{array}{l}\text { (3) } \\
\text { A-B }\end{array}$ & $\begin{array}{l}\text { (4) } \\
\text { A-B }\end{array}$ & $\begin{array}{l}(5) \\
\text { A-B }\end{array}$ & $\begin{array}{l}(6) \\
A-B\end{array}$ \\
\hline Constant & $\begin{array}{l}.78562 * * * \\
(3.93)\end{array}$ & $\begin{array}{c}.77558 * * * \\
(3.92)\end{array}$ & $\begin{array}{c}.76358 * * * \\
(3.92)\end{array}$ & $\begin{array}{c}.75523 * * * \\
(3.90)\end{array}$ & $\begin{array}{c}.72107 * * * \\
(3.86)\end{array}$ & $\begin{array}{l}.72529 * * * \\
(3.73)\end{array}$ \\
\hline Ln_GDP per capitat & $\begin{array}{l}.90174 * * * \\
(33.05)\end{array}$ & $\begin{array}{c}.90247 * * * \\
(33.20)\end{array}$ & $\begin{array}{l}.90248 * * * \\
(33.32)\end{array}$ & $\begin{array}{l}.90310 * * * \\
(33.41)\end{array}$ & $\begin{array}{l}.90001 * * * \\
(32.48)\end{array}$ & $\begin{array}{c}.90638 * * * \\
(33.09)\end{array}$ \\
\hline ln_gfcf/gdp & $\begin{array}{c}.03469 * * * \\
(3.12)\end{array}$ & $\begin{array}{c}.03446 * * * \\
(3.10)\end{array}$ & $\begin{array}{c}.03382 * * * \\
(3.09)\end{array}$ & $\begin{array}{c}.03314 * * * \\
(3.06)\end{array}$ & $\begin{array}{c}.03478 * * * \\
(3.10)\end{array}$ & $\begin{array}{c}.03211^{* * *} * \\
(3.05)\end{array}$ \\
\hline ln_refugee/pop & $\begin{array}{l}.00447 * * \\
(2.06)\end{array}$ & & & & & \\
\hline$\left(\ln \_ \text {refugee/pop }\right)^{2}$ & & & $\begin{array}{c}-.00030 * * \\
(-2.04)\end{array}$ & & & \\
\hline ln_refugee/laborforce & & $\begin{array}{c}.004472 * * \\
(2.04)\end{array}$ & & & & \\
\hline $\begin{array}{l}\text { (ln_refugee/ } \\
\text { laborforce) })^{2}\end{array}$ & & & & $\begin{array}{c}-.0003 * * * \\
(-1.99)\end{array}$ & & \\
\hline $\begin{array}{l}\text { ln_refugee*/n_labor } \\
\text { force }\end{array}$ & & & & & $\begin{array}{c}.000268^{* * *} \\
(2.01)\end{array}$ & \\
\hline ln_refugee* ln_tsja & & & & & & $\begin{array}{l}.00056^{* *} \\
(2.44)\end{array}$ \\
\hline ln_tsja & $\begin{array}{c}.00752 * * \\
(2.32)\end{array}$ & $\begin{array}{c}.00756^{* * *} \\
(2.33)\end{array}$ & $\begin{array}{c}.00730 * * \\
(2.29)\end{array}$ & $\begin{array}{c}.00741^{* *} \\
(2.32)\end{array}$ & $\begin{array}{c}.00698 * * \\
(2.17)\end{array}$ & \\
\hline ln_com & $\begin{array}{c}.023441 * * * \\
(2.60)\end{array}$ & $\begin{array}{l}.02355^{* * * *} \\
(2.61)\end{array}$ & $\begin{array}{l}.02251 * * * \\
(2.53)\end{array}$ & $\begin{array}{l}.02238 * * * \\
(2.52)\end{array}$ & $\begin{array}{c}.02219 * * * \\
(2.50)\end{array}$ & $\begin{array}{l}.02201 * * * \\
(2.51)\end{array}$ \\
\hline Wald chi2(5) & 12675.94 & 12677.03 & 12779.00 & 12806.00 & 12759.55 & 13079.73 \\
\hline Prob> chi 2 & 0.0000 & 0.0000 & 0.0000 & 0.0000 & 0.0000 & 0.0000 \\
\hline $\mathrm{N}$ ofobservations & 92 & 92 & 92 & 92 & 92 & 92 \\
\hline
\end{tabular}

Note: t-statistic in parentheses; ***, **, *: significant at 1\%, 5\% and $10 \%$ respectively; A-B: Arellano-Bond dynamic panel-data estimation.

Source: Author's calculations

Furthermore, for the high-income group and the lower-middle-income group the squared refugee rate has a negative and significant effect (the significance threshold varies from $1 \%$ for the high-income countries to $5 \%$ for the lower-middle-income countries). In fact, it is clear that when the number of refugees grows significantly, its 
effect will be negative. It is also important to note that the coefficient sign of this variable is the opposite to the one of the refugee rate variable.

This confirms the non-linear quadratic relationship between a refugee population and development in the high-income and lower-middle-income groups. Unlike previous groups, for the upper-middle and low-income groups refugees have a negative and significant impact. The elasticity of this variable varies from about -0.01 for the first group to about -0.025 for the second group and is significant at $1 \%$ level for both groups. Therefore, refugees generate a negative direct effect on these countries. Despite the fact that there is a difference between upper-middle-income group and low-income group in terms of development level, the refugee population has a negative impact on development for both groups. It is possible that it has not been integrated into the host society for several reasons such as the absence of an appropriate asylum and integration policy, the inability of the economy to absorb refugee inflows, or refugees not having the required skills. Nevertheless, the squared refugee rate has a positive and significant effect. This means that if the number of refugees grows significantly, its impact will be positive. It is possible that these economies spend unfavorably more when the number of refugees is rather small, while they can actually benefit from their presence if their number increases. The expected quadratic relationship between a refugee population and development is confirmed for both groups.

However, for the last two groups, where the effect of refugees is negative, the indirect effect of a refugee population via labor channel is negative and significant at $5 \%$ level. This demonstrates that these countries do not have the capacity to employ refugees and benefit from them at the same time. It is also possible that they do not have an appropriate asylum policy for a proper integration of refugees into their socioeconomic system, particularly in technology-intensive sector like research activity. This can be illustrated with the elasticity of GDP per capita with respect to the interactive variable $\left(\ln (\text { Refugee })_{i, t} * \ln (\operatorname{tsja})_{i, t}\right)$ which is not significant for upper-middle-income countries. For the low-income group, this elasticity is positive (equal to 0.005) and significant at $1 \%$ level.

As for the effect of control variables, the impact of lagged outcome (GDP per capita) is positive and statistically significant in all regressions (the coefficient varies from about $0.7-0.75$ for low and high-income countries to about 0.9 for the low-middle-income groups). This means that the growth is dynamic. Moreover, investment (GFCF), trade openness, and research and development (RD) play an important role in development. Hence, the elasticity of GDP per capita with respect to GFCF, which varies from about $0.02-0.035$ for middle-income countries to about 0.16 and $0.2-0.3$ for high-income and low-income countries respectively, is positive and statistically significant at $1 \%$ level for all groups except for upper-middle-income countries where it is significant at $5 \%$ level in 5 out of 6 regressions. 
Table 4: GMM results of refugees' impact on development: The case of low-income countries.

\begin{tabular}{|c|c|c|c|c|c|c|}
\hline Variable & $\begin{array}{l}(1) \\
\text { A-B }\end{array}$ & $\begin{array}{l}(2) \\
\text { A-B }\end{array}$ & $\begin{array}{l}(3) \\
\text { A-B }\end{array}$ & $\begin{array}{l}(4) \\
\text { A-B }\end{array}$ & $\begin{array}{l}(5) \\
\text { A-B }\end{array}$ & $\begin{array}{l}(6) \\
\text { A-B }\end{array}$ \\
\hline Constant & $\begin{array}{l}1.6490 * * * \\
\quad(3.74)\end{array}$ & $\begin{array}{l}1.6659 * * * \\
(3.79)\end{array}$ & $\begin{array}{c}1.6634 * * * \\
(3.80)\end{array}$ & $\begin{array}{l}1.6590 * * * \\
(3.81)\end{array}$ & $\begin{array}{l}1.8542 * * * \\
(4.14)\end{array}$ & $\begin{array}{l}1.4726 * * * \\
\quad(3.02)\end{array}$ \\
\hline Ln_GDP per capita ${ }_{\mathrm{t}-1}$ & $\begin{array}{l}.70886^{* * * *} \\
(10.25)\end{array}$ & $\begin{array}{l}.70910 * * * \\
(10.27)\end{array}$ & $\begin{array}{l}.71328 * * * \\
(10.37)\end{array}$ & $\begin{array}{l}.71420 * * * \\
(10.42)\end{array}$ & $\begin{array}{c}.72478 * * * \\
(10.06)\end{array}$ & $\begin{array}{l}.76411^{* * * *} \\
(10.07)\end{array}$ \\
\hline ln_gfcf/gdp & $\begin{array}{l}.28162 * * * \\
(6.79)\end{array}$ & $\begin{array}{l}.28319 * * * \\
(6.82)\end{array}$ & $\begin{array}{c}.28947 * * * \\
(6.92)\end{array}$ & $\begin{array}{l}.29281 * * * \\
(7.00)\end{array}$ & $\begin{array}{c}.26120 * * * \\
(6.19)\end{array}$ & $\begin{array}{c}.20085^{* * * *} \\
(4.88)\end{array}$ \\
\hline ln_refugee/pop & $\begin{array}{c}-.0241 * * * \\
(-3.12)\end{array}$ & & & & & \\
\hline$(\text { ln_refugee/pop })^{2}$ & & & $\begin{array}{c}.00274 * * * \\
(3.31)\end{array}$ & & & \\
\hline ln_refugee/laborforce & & $\begin{array}{c}-.0247 * * * \\
(-3.19)\end{array}$ & & & & \\
\hline $\begin{array}{l}\text { (ln_refugee/ } \\
\text { laborforce) })^{2}\end{array}$ & & & & $\begin{array}{c}.00349 * * * \\
(3.45)\end{array}$ & & \\
\hline $\begin{array}{l}\text { ln_refugee* }{ }^{*} \text { ln_labor } \\
\text { force }\end{array}$ & & & & & $\begin{array}{c}-.00113 * * \\
(-1.97)\end{array}$ & \\
\hline ln_refugee* 1 n_tsja & & & & & & $\begin{array}{c}.00479 * * * \\
(4.23)\end{array}$ \\
\hline ln_tsja & $\begin{array}{c}.07333 * * * \\
(5.71)\end{array}$ & $\begin{array}{l}.07288 * * * \\
(5.67)\end{array}$ & $\begin{array}{l}.07461 * * * \\
(5.87)\end{array}$ & $\begin{array}{l}.07484 * * * \\
(5.91)\end{array}$ & $\begin{array}{l}.07610 * * * \\
(5.82)\end{array}$ & \\
\hline ln_com & $\begin{array}{c}-.1670 * * * \\
(-6.06)\end{array}$ & $\begin{array}{c}-.1683 * * * \\
(-6.09)\end{array}$ & $\begin{array}{c}-.1782 * * * \\
(-6.17)\end{array}$ & $\begin{array}{c}-.1838 * * * \\
(-6.25)\end{array}$ & $\begin{array}{c}-.1552 * * * \\
(-5.33)\end{array}$ & $\begin{array}{c}-.0856 * * * \\
(-3.43)\end{array}$ \\
\hline Wald chi2(5) & 992.09 & 994.93 & 1006.54 & 1013.59 & 945.73 & 771.90 \\
\hline Prob> chi 2 & 0.0000 & 0.0000 & 0.0000 & 0.0000 & 0.0000 & 0.0000 \\
\hline $\mathrm{N}$ ofobservations & 91 & 91 & 91 & 91 & 91 & 91 \\
\hline
\end{tabular}

Note: $t$-statistic in parentheses; ***, **, *: significant at 1\%, 5\% and $10 \%$ respectively; A-B: Arellano-Bond dynamic panel-data estimation.

Source: Author's calculations

Investment remains the major determinant of growth and development in both developed and developing countries. It is also clear that trade openness significantly contributes to development in all regressions except for those the low-income group where the elasticity of this variable is negative and significant at $1 \%$ level (it varies from about 0.04 to 0.08 ). This unexpected effect of trade can be explained by an unequal trade between these low-technology countries with the technologically developed ones. For such countries, exports are less intensive than imports, which strengthen the trade deficit and consequently negatively affect economic growth. The sign of the elasticity of GDP per capita with respect to RD variable is expected for all groups. This elasticity is ranging from about 0.007 to about 0.075 and is positive and significant at $1 \%$ and $5 \%$ levels for all groups. Therefore, RD activity constitutes an important factor of development in all countries, particularly in developed ones. 


\section{Concluding remarks and policy implications}

The aim of this study is to investigate the relationship between refugees and development in host economies. This relationship has previously only been investigated with microeconometric studies based on survey data. However, it is difficult to aggregate conclusions useful for larger-scale cases from this microeconometric approach (Baez, 2011). Therefore, the objective of this study is to remedy that and investigate this relationship from a macroeconomic point of view. Only a few studies have analyzed this effect. Also, to the best of our knowledge, there has not previously been a study that would treat the nature of this relationship. The findings of this paper show that the relationship between a refugee population and development is non-linear. In the empirical chapter, the effect of refugees on GDP per capita growth is tested. We have estimated a dynamic panel model for 4 country-groups. The results demonstrate that refugees have a positive and significant direct effect for high and lower-middleincome countries, and they also generate a positive and significant indirect effect through both labor force and RD channels. Nevertheless, when the population of refugees significantly increases, they can have a negative and significant impact on development of these two groups. As for the rest of the groups, the direct effect of refugees is negative and significant. Similarly, the indirect effect of a refugee population on development through labor force channel is also negative and statistically significant in this case. However, the indirect effect of refugees through RD channel is statistically significant only for the low-income group. It is hence possible that the refugees need a relatively long integration period in which they can contribute to growth in the uppermiddle and low-income economies. These economies also need an optimal number of refugees in order to benefit from them: the estimations calculated for both of these groups show that the elasticity of GDP per capita with respect to squared refugee rate is positive and statistically significant.

Finally, it is important to note that despite the fact that some countries, especially developed ones, have managed to adopt an efficient asylum policy, other countries have not optimally benefited from refugees. Based on these findings, certain policy implications can be proposed:

First of all, refugees cannot be considered only as a negative source of development in host countries. On the contrary: they can also stimulate positive effects. In fact, they can contribute to economic growth by enhancing labor supply, increasing productivity, increasing human capital and, therefore, research and development activity as well. Regarding the increase in productivity, it is quite likely that the effort of a refugee worker could be greater than that of a local citizen or a regular migrant worker due to their extreme situation. If a refugee manages to find employment, they try to provide their maximum effort in order to keep the job. This could also result in a psychological effect on workers local to the host country by motivating them to exceed the verve of their refugee colleagues. Furthermore, the host economy can benefit from remittances, humanitarian aids and funds. For these many reason, host economies, particularly highincome economies, can optimally benefit from a refugee population. There is hence a need for an international community as well as international NGOs such as UNHCR to develop and sustain an international legal framework in order to reach an optimal 
situation in which both skilled and unskilled refugees are considered to be an economic and human potential, not a problem for the host society.

This paper studies the relationship between refugees and development from a macroeconomic point of view, and, to the best of our knowledge, it constitutes the first attempt in the investigation of the nature of this relationship. Future empirical works could examine this relationship while taking into account some other important aspects. For example, it would be useful to conduct a study on the optimal rate of refugees to inform policy-makers in host countries about the optimal number of refugees that should be taken in without any damage to their economies. It is also important to consider the skill level of refugees in order to distinguish between the effect of skilled and unskilled refugees.

Disclosure statement: No potential conflict of interests was reported by the author.

\section{References}

ALIX-GARCIA J., SAAH D. (2008). The effect of refugee inflows on host communities: evidence from Tanzania. Working Paper, University of San Francisco. Available at: http://ssrn.com/abstract=836147.

ARELLANO M., BOND S. (1991). Some Tests of Specification for Panel Data: Monte Carlo Evidence and an Application to Employment Equations. Review of Economic Studies 58: 277-297

ARELLANO M., BOVER O. (1995). Another look at the instrumental variable estimation of error-components models. Journal of Econometrics 68: 29-51

BAEZ J. E. (2011). Civil wars beyond their borders: The human capital and health consequences of hosting refugees. Journal of Development Economics 96(2): 391-408.

BLUNDELL R., BOND S. (1998). Initial conditions and moment restrictions in dynamic panel data models. Journal of Econometrics 87: 115-143. DOI: 10.1016/S0304-4076(98)00009-8

BORJAS G. J. (1994). The economics of immigration. Journal of Economic Literature XXXII: 1667-1717.

FREIDBERG R. M., Hunt J. (1995). The impact of immigrants on host country wages, employment and growth. The Journal of Economic Perspectives 9(2): 23-44. DOI: 10.1257/jep.9.2.23

GOMEZ M. P., CHRISTENSEN A., ARAYA Y. Y., HARILD N. (2010). The impacts of refugees on neighboring countries: a development challenge. World Development Report background papers, 2011. Washington, DC: World Bank.

GROSSMAN G., HELPMAN E. (1991). Innovation and Growth in the Global Economy. MIT Press, Cambridge MA. 
JACOBSEN K. (2002). Can refugees benefit the state? Refugee resources and African state building. Journal of Modern African Studies 40(4): 577-596. DOI: 10.1017/S0022278X02004081

JACOBSEN, K. (2001). The forgotten solution: Local integration for refugees in developing countries. New issues in refugee research paper, 45.

KIBREAB G. (1985). African refugees: Reflections on the African refugee problem. Trenton, NJ, USA: Africa World Press.

KREIBAUM M. (2016). Their Suffering, Our Burden? How Congolese Refugees Affect the Ugandan Population. World Development 78: 262-287. DOI: 10.1016/j.worlddev.2015.10.019

LI P. S. (2008). World Migration in the Age of Globalization: Policy Implications and Challenges. New Zealand Population Review 33/34: 1-22.

MAYSTADT, J., VERWIMP Ph. (2009). Winners and losers among a refugee-hosting population. CORE Discussion paper. May.

ROMER P. M. (1990). Endogenous technological change. Journal of political economy 98(5): 71-102. DOI: $10.1086 / 261725$

SHELLITO, K. (2016). The Economic Effect of Refugee Crises on Host Countries and Implications for the Lebanese Case. Joseph Wharton Research Scholars. Available at http://repository.upenn.edu/joseph_wharton_scholars/3

UNHCR, (2010). Convention and protocol relating to the status of refugees. www.unhcr.org 


\section{Appendix}

\section{A1: Descriptive statistics}

Table A11. High-income countries

\begin{tabular}{|c|c|c|c|c|c|c|}
\hline Variable & & Mean & Std. Dev. & Min & Max & Observations \\
\hline \multirow{3}{*}{ Ln_GDP per capita } & Overall & \multirow{3}{*}{10.26353} & .5668289 & 8.692096 & 11.02108 & 225 \\
\hline & Between & & .5843379 & 9.046709 & 10.89666 & 9 \\
\hline & Within & & .1281729 & 9.908914 & 10.50904 & 25 \\
\hline \multirow{3}{*}{ ln_gfcf/gdp } & Overall & \multirow{3}{*}{-1.572291} & .1777181 & -2.154968 & -1.169475 & 225 \\
\hline & Between & & .1372592 & -1.784977 & -1.348016 & 9 \\
\hline & Within & & .1214998 & -2.151636 & -1.329676 & 25 \\
\hline \multirow{3}{*}{ In_refugee/pop } & Overall & \multirow{3}{*}{-6.81456} & 1.781329 & -10.91611 & -4.04713 & 225 \\
\hline & Between & & 1.599548 & -9.041025 & -4.673539 & 9 \\
\hline & Within & & .942713 & -10.45147 & -4.032168 & 25 \\
\hline \multirow{3}{*}{$\begin{array}{l}\text { ln_refugee/labor } \\
\text { force }\end{array}$} & Overall & \multirow{3}{*}{-6.049298} & 1.73303 & -9.981877 & -3.313208 & 225 \\
\hline & Between & & 1.525243 & -8.199801 & -3.979368 & 9 \\
\hline & Within & & .9624344 & -9.862442 & -3.193772 & 25 \\
\hline \multirow{3}{*}{ ln_tsja } & Overall & \multirow{3}{*}{9.73209} & 1.66207 & 6.40506 & 12.96345 & 225 \\
\hline & Between & & 1.64980 & 7.35029 & 12.54226 & 9 \\
\hline & Within & & .576409 & 8.46536 & 11.42989 & 25 \\
\hline \multirow{3}{*}{ ln_com } & Overall & \multirow{3}{*}{-1.30254} & .532345 & -2.49504 & -.141029 & 224 \\
\hline & Between & & .392610 & -1.83387 & -.864609 & 9 \\
\hline & Within & & .381704 & -2.09349 & -.537350 & $\begin{array}{l}\text { T-bar }= \\
24.8889\end{array}$ \\
\hline \multirow{3}{*}{$\begin{array}{l}\text { ln_refugee*/n_labor } \\
\text { force }\end{array}$} & Overall & \multirow{3}{*}{175.665} & 43.1364 & 102.216 & 257.308 & 225 \\
\hline & Between & & 43.0915 & 127.654 & 243.9328 & 9 \\
\hline & Within & & 14.2414 & 125.264 & 221.9971 & 25 \\
\hline \multirow{3}{*}{ ln_refugee* ${ }^{*}$ ln_tsja } & Overall & \multirow{3}{*}{104.412} & 34.5623 & 50.6490 & 174.9908 & 225 \\
\hline & Between & & 35.7537 & 68.9718 & 162.6166 & 9 \\
\hline & Within & & 7.29318 & 84.9113 & 129.8083 & 25 \\
\hline
\end{tabular}

Source: Author's calculations 
Table A12. Upper-middle-income countries

\begin{tabular}{|c|c|c|c|c|c|c|}
\hline Variable & & Mean & Std. Dev. & Min & $\operatorname{Max}$ & Observations \\
\hline \multirow{3}{*}{ Ln_GDP per capita } & Overall & \multirow{3}{*}{8.659926} & .5200639 & 7.501546 & 9.375639 & 100 \\
\hline & Between & & .5324977 & 7.906716 & 9.139423 & 4 \\
\hline & Within & & .2359088 & 8.183817 & 9.194858 & 25 \\
\hline \multirow{3}{*}{ ln_gfcf/gdp } & Overall & \multirow{3}{*}{$\begin{array}{c}-1.559674 \\
.\end{array}$} & 3977615 & -3.258096 & -.8304305 & 100 \\
\hline & Between & & .2432442 & -1.842987 & -1.290491 & 4 \\
\hline & Within & & .3367346 & -2.974783 & -.7478031 & 25 \\
\hline \multirow{3}{*}{ In_refugee/pop } & Overall & \multirow{3}{*}{-7.962261} & 1.85681 & -11.75922 & -5.316039 & 100 \\
\hline & Between & & 1.85561 & -10.74326 & -6.950238 & 4 \\
\hline & Within & & .9160745 & -12.77124 & -6.260002 & 25 \\
\hline \multirow{3}{*}{$\begin{array}{l}\text { ln_refugee/labor } \\
\text { force }\end{array}$} & Overall & \multirow{3}{*}{-7.103488} & 1.914989 & -10.82568 & -4.523891 & 100 \\
\hline & Between & & 1.947687 & -10.02412 & -6.067848 & 4 \\
\hline & Within & & .8906903 & -11.86131 & -5.441948 & 25 \\
\hline \multirow{3}{*}{ ln_tsja } & Overall & \multirow{3}{*}{5.659602} & 3.158895 & -.223143 & 10.92312 & 100 \\
\hline & Between & & 3.393528 & 1.738329 & 9.39699 & 4 \\
\hline & Within & & 1.11998 & 3.69813 & 8.268442 & 25 \\
\hline \multirow{3}{*}{ ln_com } & Overall & \multirow{3}{*}{$\begin{array}{c}- \\
.8226939\end{array}$} & 1.073121 & -3.13250 & .3587438 & 100 \\
\hline & Between & & 1.118154 & -2.37643 & .0668615 & 4 \\
\hline & Within & & .4521229 & -1.81545 & .1572309 & 25 \\
\hline \multirow{3}{*}{$\begin{array}{l}\text { ln_refugee* }{ }^{*} \ln \_ \text {labor } \\
\text { force }\end{array}$} & Overall & \multirow{3}{*}{143.2731} & 24.94769 & 79.8993 & 188.7478 & 100 \\
\hline & Between & & 21.52902 & 112.2829 & 161.959 & 4 \\
\hline & Within & & 16.46972 & 61.2134 & 175.1879 & 25 \\
\hline \multirow{3}{*}{ ln_refugee* ${ }^{*}$ In_tsja } & Overall & \multirow{3}{*}{50.84755} & 30.55218 & -2.06833 & 114.7309 & 100 \\
\hline & Between & & 30.54621 & 16.63723 & 77.80476 & 4 \\
\hline & Within & & 15.05203 & 4.057276 & 90.17742 & 25 \\
\hline
\end{tabular}

Source: Author's calculations 
Table A13. Lower-middle-income countries

\begin{tabular}{|c|c|c|c|c|c|c|}
\hline Variable & & Mean & Std. Dev. & Min & $\operatorname{Max}$ & Observations \\
\hline \multirow{3}{*}{ Ln_GDP per capita } & Overall & \multirow{3}{*}{6.994426} & .5190842 & 5.992111 & 7.889098 & 100 \\
\hline & Between & & .5514766 & 6.34117 & 7.63309 & 4 \\
\hline & Within & & .1976097 & 6.645367 & 7.482034 & 25 \\
\hline \multirow{3}{*}{ ln_gfcf/gdp } & Overall & \multirow{3}{*}{-1.632987} & .2815039 & -2.893326 & -1.252537 & 100 \\
\hline & Between & & .1854004 & -1.868562 & -1.466504 & 4 \\
\hline & Within & & .23066 & -2.657751 & -1.172641 & 25 \\
\hline \multirow{3}{*}{ In_refugee/pop } & Overall & \multirow{3}{*}{-6.582273} & 1.887711 & -13.50206 & -2.965595 & 100 \\
\hline & Between & & 1.687631 & -8.00845 & -4.555532 & 4 \\
\hline & Within & & 1.185665 & -12.07588 & -4.584277 & 25 \\
\hline \multirow{3}{*}{$\begin{array}{l}\text { ln_refugee/labor } \\
\text { force }\end{array}$} & Overall & \multirow{3}{*}{-5.565995} & 1.941428 & -12.67441 & -1.71694 & 100 \\
\hline & Between & & 1.777613 & -7.227593 & -3.338735 & 4 \\
\hline & Within & & 1.172719 & -11.01281 & -3.632193 & 25 \\
\hline \multirow{3}{*}{ ln_tsja } & Overall & \multirow{3}{*}{5.717654} & 1.832391 & .6931472 & 9.213514 & 100 \\
\hline & Between & & 1.683019 & 4.240565 & 7.953243 & 4 \\
\hline & Within & & 1.10081 & 2.170236 & 7.384013 & 25 \\
\hline \multirow{3}{*}{ ln_com } & Overall & \multirow{3}{*}{-1.53574} & .6270018 & -3.34286 & -.438839 & 100 \\
\hline & Between & & .4719779 & -2.12630 & -.975917 & 4 \\
\hline & Within & & .4736784 & -2.75229 & -.536805 & 25 \\
\hline \multirow{3}{*}{$\begin{array}{l}\text { ln_refugee*1n_labor } \\
\text { force }\end{array}$} & Overall & \multirow{3}{*}{180.7619} & 26.97875 & 87.84504 & 224.6993 & 100 \\
\hline & Between & & 19.77981 & 157.8773 & 201.7039 & 4 \\
\hline & Within & & 20.77158 & 76.6375 & 222.1022 & 25 \\
\hline \multirow{3}{*}{ ln_refugee* ${ }^{*}$ ln_tsja } & Overall & \multirow{3}{*}{62.09028} & 21.08375 & 7.603925 & 113.9893 & 100 \\
\hline & Between & & 16.04799 & 43.09097 & 81.67447 & 4 \\
\hline & Within & & 15.79304 & 20.21288 & 94.40513 & 25 \\
\hline
\end{tabular}

Source: Author's calculations 
Table A14. Low-income countries

\begin{tabular}{|c|c|c|c|c|c|c|}
\hline Variable & & Mean & Std. Dev. & Min & Max & Observations \\
\hline \multirow{3}{*}{ Ln_GDP per capita } & Overall & \multirow{3}{*}{6.133399} & .2310998 & 5.310416 & 6.670644 & 100 \\
\hline & Between & & .1420972 & 6.005962 & 6.316461 & 4 \\
\hline & Within & & .195219 & 5.437852 & 6.620279 & 25 \\
\hline \multirow{3}{*}{ ln_gfcf/gdp } & Overall & \multirow{3}{*}{-1.644709} & .2522859 & -2.304336 & -1.088692 & 100 \\
\hline & Between & & .1637246 & -1.798681 & -1.444721 & 4 \\
\hline & Within & & .2081845 & -2.150364 & -1.211166 & 25 \\
\hline \multirow{3}{*}{ In_refugee/pop } & Overall & \multirow{3}{*}{-4.984551} & 1.180277 & -7.244483 & -2.452699 & 100 \\
\hline & Between & & .5607601 & -5.556005 & -4.39895 & 4 \\
\hline & Within & & 1.074632 & -7.830084 & -2.747293 & 25 \\
\hline \multirow{3}{*}{$\begin{array}{l}\text { ln_refugee/labor } \\
\text { force }\end{array}$} & Overall & \multirow{3}{*}{-4.225555} & 1.219103 & -6.358388 & -1.53499 & 100 \\
\hline & Between & & .6469934 & -4.884255 & -3.48201 & 4 \\
\hline & Within & & 1.081245 & -7.101934 & -1.958443 & 25 \\
\hline \multirow{3}{*}{ ln_tsja } & Overall & \multirow{3}{*}{3.496733} & 1.710353 & .6931472 & 6.226136 & 100 \\
\hline & Between & & 1.647302 & 1.710574 & 5.120808 & 4 \\
\hline & Within & & .9324951 & 1.842381 & 5.608986 & 25 \\
\hline \multirow{3}{*}{ ln_com } & Overall & \multirow{3}{*}{-1.41674} & .5430908 & -2.41209 & -.203917 & 99 \\
\hline & Between & & .4176937 & -1.76001 & -.813479 & 4 \\
\hline & Within & & .4063282 & -2.06883 & -.320637 & $\begin{array}{c}\text { T-bar = } \\
24.75\end{array}$ \\
\hline \multirow{3}{*}{$\begin{array}{l}\text { ln_refugee* }{ }^{*} \text { ln_labor } \\
\text { force }\end{array}$} & Overall & \multirow{3}{*}{183.8766} & 24.20584 & 129.4057 & 225.3176 & 100 \\
\hline & Between & & 22.24449 & 160.6126 & 213.2005 & 4 \\
\hline & Within & & 14.52794 & 148.2373 & 209.9493 & 25 \\
\hline \multirow{3}{*}{ ln_refugee* ${ }^{*}$ ln_tsja } & Overall & \multirow{3}{*}{40.99546} & 21.52177 & 9.16587 & 73.60741 & 100 \\
\hline & Between & & 21.79569 & 18.84363 & 65.15844 & 4 \\
\hline & Within & & 10.16361 & 17.12277 & 65.96926 & 25 \\
\hline
\end{tabular}

Source: Author's calculations

\section{A2. Country groups consistent with the 2014 World Bank classification}

\begin{tabular}{|l|l|}
\hline Group & Income-group \\
\hline High-incomegroup & $\begin{array}{l}\text { Argentina, Australia, Denmark, Germany, } \\
\text { Greece, Saudi Arabia, Spain, United } \\
\text { Kingdom, United States of America. }\end{array}$ \\
\hline Upper-middle-incomegroup & Angola, Brazil, Malaysia, Panama. \\
\hline Lower-middle-incomegroup & Bangladesh, Egypt, Senegal, Sudan. \\
\hline Low-incomegroup & Guinea, Nepal, Rwanda, Tanzania. \\
\hline
\end{tabular}




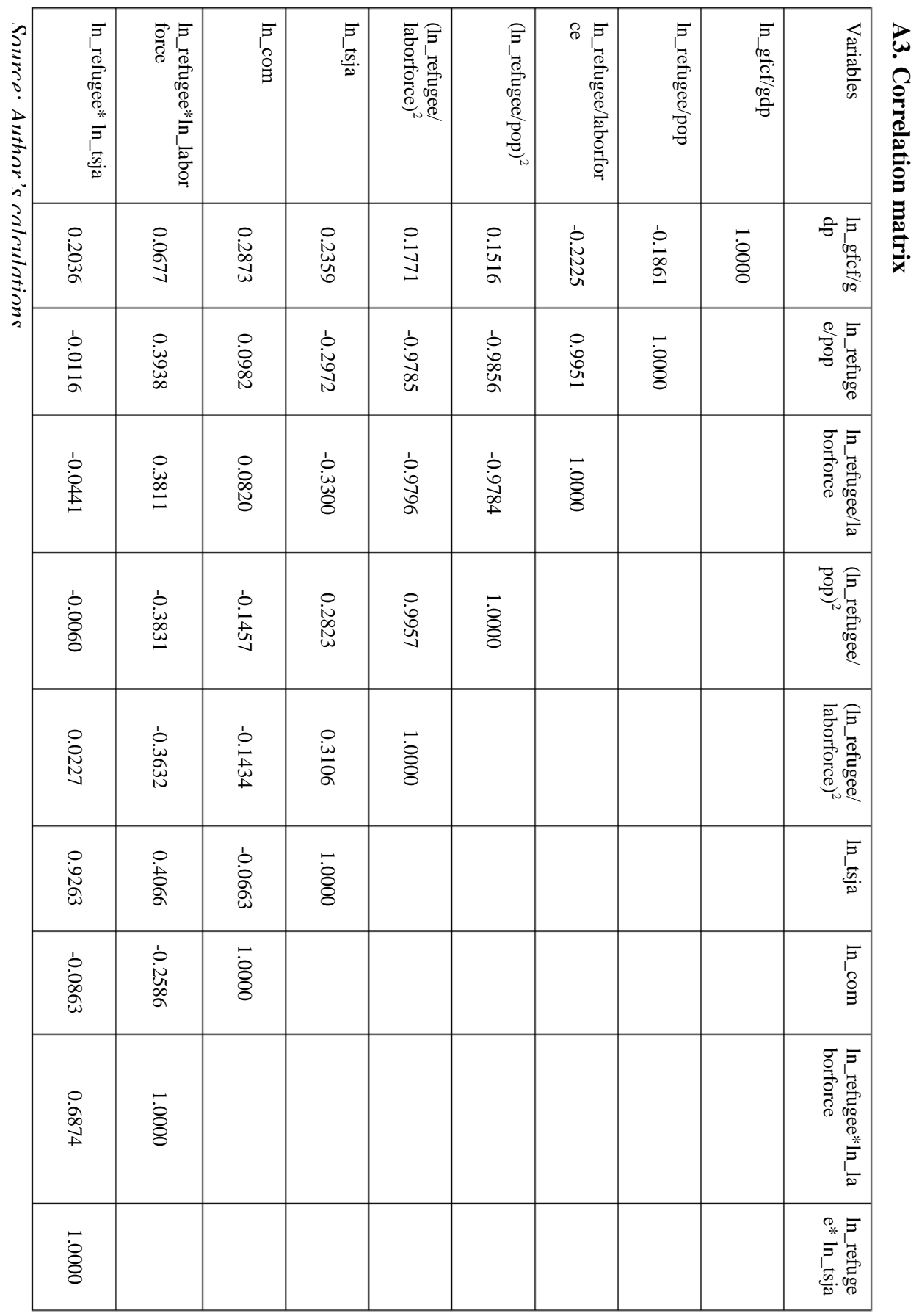

